ISSN 1412-2936

EISSN 2549-7308

\title{
PENGARUH PENERBITAN SAHAM DAN OBLIGASI TERHADAP SUSTAINABILITY DISCLOSURE DENGAN MODERASI PENGAWASAN DAN PENGARUH KELUARGA
}

\author{
Endang Ranitawati \\ endangranitawati@Yahoo.co.id \\ SEKOLAH TINGGI ILMU EKONOMI INDONESIA (STIESIA) SURABAYA
}

\begin{abstract}
ABSTRAK
Tujuan dari penelitian ini menganalisis pengaruh penerbitan saham dan obligasi terhadap sustainability ddisclosure dengan pengawasan dan pengaruh keluarga sebagai variabel moderating. Pengambil sampel berdasarkan pada perusahaan yang terdaftar di Bursa Efek Indonesia yang telah menerbitkan sustainability disclossure pada tahun 2013 - 2015. Metode puposive sampling merupakan metode pemilihan sampel yang digunakan. Ordinary least squre merupakan teknik analisis yang digunakan. Hasil pengungkapan bahwa penerbitan saham tidak berpengaruh secara positif tehadap sustainability disclosure, akan tetapi penerbitan obligasi yang berpengaruh secara positif signifikan terhadap sustainability disclosure. Selain daripada itu bahwa variabel moderating pengawasan dan pengaruh keluarga tidak dapat memoderasi hubungan antara penerbitan saham dan obligasi dengan sustainability disclosure.
\end{abstract}

Kata Kunci : Penerbitan Saham, Penerbitan Obligasi, Sustainability Disclosure, Pengawasan dan Pengaruh Keluarga

\section{ABSTRACT}

The purpose of this study is to analyze the effect of stock and bond issuance on sustainability disclosure with supervision and family influence as moderating variables. This study took samples based on companies listed on the Indonesia Stock Exchange that had issued sustainability disclosures in 2013 - 2015. Puposive sampling method was a method of selecting samples used. Ordinary least squre is an analytical technique used.This study succeeded in revealing that the issuance of shares does not have a positive effect on sustainability disclosure, but the issuance of bonds that have a significantly positive effect on sustainability disclosure. Besides that, moderating variables of supervision and family influences cannot moderate the relationship between the issuance of shares and bonds with sustainability disclosure.

Keywords : Issuance of Shares, Bond Issuance, Sustainability Disclosure, Monitoring and Family Influence.

PENDAHULUAN

Pengungkapan CSR telah banyak dimanfaatkan untuk menilai perusahan oleh para profesional akhit-akhir tahun ini (Gao et al, 2015). Investor-investor dapat menilai dan menentukan keputusan mengenai penerapan kegiatan di perusahaan dengan pengungkapan CSR dalam laporan tahunan untuk mendapat tanggapan dari investor, dalam rangka mempengaruhi kelangsungan hidup perusahaan akan datang dibidang kekuatan keuangan. Demikian sebaliknya, investor maupun 
calon investor membutuhkan sustainability disclosure, sebagai bahan pertimbangan untuk menginvestasikan modalnya atau tidak pada perusahaan tersebut disertai dengan penambahan biaya operasional.

Penerbitan saham ataupun obligasi merupakan sumber peningkatan modal bagi perusahaan. Untuk saat ini lingkungan perusahaan dan kegiatan sosial menjadi topik yang menarik bagi investor, untuk itu para pemodal akan mempertimbangkan sustainability disclosure menjadi salah satu sarana. Data non finansial yang dapat menekan kecemasan pemodal terhadap risiko penanaman modal adalah Sustainability disclosure (Healy dan Palepu, 2001). Sikap positif terhadap sustainability disclosure menunjukan kepentingan pembiayaan eksternal pada perusahaan yang lebih besar. (Francis et al, 2005).

Pengungkapan segi finansial dan non finansial perusahaan dari sustainability disclosure, diharapkan pemodal bisa lebih menguasai informasi perusahaan yang berkorelasi dengan kinerja dan berkesinambungan (Rusamanto, et. all, 2015). Keberadaan sustainability disclosure di Indonesia diatur dalam peraturan yang mengatur kegiatan CSR (Corporate Social Responsibility), yaitu pasal 74 ayat (1) UU Perseroan Terbatas No. 40 Tahun 2007 menjelaskan bahwa tanggung jawab sosial dan lingkungan wajib dilaksanakan oleh perusahaan yang beroperasional dibidang yang berkaitan dengan sumber daya alam. Pernyataan tersebut juga tertuang dalam PP No. 47 tahun 2012. Dukungan peraturan tersebut menjadikan perusahaan yang telah menerbitkan sustainability disclosure meningkat sebesar lima belas persen (NCSR, 2015).

Penelitian yang dilakukan

Campopiano, G. \& De Massis, A, 2014 memperlihatkan bahwa pengungkapan kegiatan sosial dan lingkungan ada perbedaan antara perusahaan keluarga dan non keluarga dilihat dari karakteristik khusus yang dimiliki perusahaan keluarga tentang prosedur usaha, seperti, tata kelola manufaktur, terobosan dan pendanaan. Ketergantungan pada kedatangan keluarga yang berpartisipasi bisnis dan kekhususan perilaku mereka merupakan sasaran ekonomi dan non-ekonomi di perusahaan keluarga (Kotlar, J., \& De Massis, A, 2013). Pelestarian socioemotional wealth yang diwujudkan oleh Perusahaan keluarga dalam peningkatan yang keberlanjutan bagi perusahaannya, untuk mencukupi keperluan keluarga, seperti jati diri, kekuatan menerapkan pengaruh keluarga, dan loyalitas dari keluarga" (Gomez Mejia et al, 2007).

Persoalan lain yang dihadapi oleh perusahaan keluarga, yakni persoalan keagenan, hal ini dikarenakn mayoritas kepemilikan saham dan pengendalian terhadap dewan direksi secara signifikan dilaksanakan oleh keluarga. Pada perusahaan keluarga jajaran dewan direksi memiliki kecenderungan yang kurang otonomi dan dikuasai oleh personel keluarga (Anderson, R.C. \& Reeb, D.M, 2003). Selain itu manipulasi laba akuntansi juga merupakan salah satu wujud permasalahan yang disebabkan keagenan sebagai contoh, untuk menggelapkan efek negatif dari transaksi sisi terikat atau untuk memudahkan pengukuhan personel keluarga dalam kedudukan pengelola. (Ali, A, et/ all, 2007)

$$
\text { Gavanna (2017) berupaya }
$$

mengkaji tautan antara penerbitan surat berharga (saham dan obligasi) dengan kualitas pengungkapan sustainability disclosure pada badan usaha milik keluarga dan badan usaha bukan milik keluarga dan juga meneliti dampak fase inspeksi keluarga terhadap sustainability disclosure. Dengan sustainability disclosure investor dapat memperoleh penjelasan dalam menyusun penilaian risiko lebih sempurna sehingga dapat menekan asimetri informasi dan ancaman yang memberatkan. (Reverte, 2014)

$$
\text { Penelitian Gavana }
$$

menandai bahwa pengontrolan pelaksanaan agency theori dan institutional theory dari dimensi perusahaan non keluarga dan 
perusahaan keluarga dilakukan apabila perusahaan telah menetapkan pilihan pendanaan yang dapat mempengaruhi sustainability disclosure, selain itu penentuan pilihan pendanaan perusahaan akibat adanya perbedaan perilaku perusahaan keluarga dan non keluarga.

Selaras dengan teori institusional dan teori agensi (Gavanna, 2017) memprediksi bahwa terdapat korelasi aktual antara sustainability disclosure dengan publikasi saham maupun publikasi obligasi. Memfasilitasi peningkatan modal ekternal, perusahaan menggunakan sustainability disclosure. Sedangkan untuk mengevaluasi kepemilikan sekuritas dan otoritas yang signifikan dari keluarga atas dewan direksi di perusahaan menggunakan teori agensi karena dewan direksi perusahaan keluarga mengarah pada otonomi terbatas serta dikuasai oleh personel keluarga (Anderson dan Reeb, 2004).

Pengujian cost of equity capital yang dipengaruhi corporate social responsibility disclosure telah dilakukan El Ghoul et al (2011). Hasil penelitiannya menunjukkan bahwa cost of equity lebih rendah ditunjukkan dengan nilai CSR perusahaan yang lebih tinggi. Beda dengan hasil penelitian Reverte (2011) menguji cost of equity capital dipengaruhi sustainability disclosure, menunjukkan hasil korelasi signifikan tapi negatif antara cost of equity capital dan fase pengungkapan CSR. Selanjutnya Giovanna Campociano dan Alfredo De Massis ( 2014) mendiskripsikan penelitiannya sebagai berikut ; kebanyakan perusahaan non keluarga dan perusahaan keluarga mendistribusikan laporan Corporate Social Responsibility kurang sinkron dengan standar Corporate Social Responsibility serta memposisikan pemusatan topik Corporate Social Responsibility yang berlainan. Sedangkan pendiskripsian hasil penelitian Gavana (2017) menunjukkan bahwa dalam perkara publikasi saham inspeksi keluarga mempunyai pengaruh bias bahkan tidak mempengaruhi pengungkapan dalam perkara obligasi.
Mengacu pada penelitian yang dilakukan Gavanna tahun 2017, pemilahan tema penelitian ini mempunyai misi untuk mengkaji pengaruh dominan karakteristik pengungkapan dengan memanfaatkan sustainability disclosure sebagai fasilitas untuk menaikkan kapital eksternal dan kepemilikan sekuritas perusahaan di Indonesia yang terdaftar aktif di BEl. Global Reporting Initiative versi G4 dipakai sebagai indikator evaluasi sustainability disclosure dalam penelitian ini (Gavanna, 2017). Indikator tanggungjawab produk, tenaga kerja, sosial, lingkungan, dan masyarakat nantinya yang akan dievaluasi pada penelitian ini.

Perusahaan

dievaluasi keterandalannya bukan hanya berlandaskan report tahunannya saja akan tetapi report yang berhubungan dengan aktivitas lingkungan sosial yang sudah dilaksanakan merupakan perwujudan tanggungjawab kepada pemegang saham dan pemangku kepentingan dapat menggunakan Sustainability disclosure (Campopiano, 2014). Schadewitz dan Niskala (2010) penelitiannya memperlihatkan nilai pasar perusahaan dipengaruhi secara positif oleh report tanggungjawab lingkungan sosial dilaksanakan perusahaan. Dengan kata lain, tambahan dana dari pemangku kepentingan dapat diperoleh perusahaan yang merencanakan untuk mempublikasikan saham dan obligasi dengan syarat perusahaan memberikan sustainability disclosure yang bernilai tinggi. Banyak pemodal akan tertarik apabila perusahaan memberikan tingkat sustainability disclosure tinggi. Oleh karena itu, terdapat hubungan antara sustainability disclosure dan pempublikasian saham dan obligasi.

Di Indonesia antara perusahaan keluarga dan non keluarga proses sustainability disclosure berlainan yang tampak pada tata kelola perusahaan, perubahan dan pendanaan (Campopiano, 2014). Aspek nomor satu SEW adalah merujuk pada dampak dari inspeksi keluarga (Berrone et al, 2012). Melalui CEO dampak dari inspeksi 
keluarga bermula dari personel keluarga dengan pemberian inspeksi terhadap ketetapan kebijakan yang diambil perusahaan keluarga (Schulze, Lubatkin, \& Dino, 2003). Timbulnya konflik antara kepemilikan sekuritas dan otoritas keluarga atas dewan direksi membuatkan persoalan keagenan. Dewan direksi perusahaan keluarga condong pada keterbatasan otonomi yang dikuasai personel keluarga (Anderson dan Reeb, 2004). maka, diperlukan dua teori yaitu teori keagenan (agensi teori) dan teori institusional untuk menjelaskan pergerakan perkembangan antara penerbitan sekuritas, sustainability disclosure, dan pengawasan keluarga.

Berdasarkan uraian di atas dapat diambil rumusan permasalahan sebagai berikut apakah penerbitan saham dan penerbitan obligasi berpengruh terhadap sustainabiliity disclosure. Apakah hubungan sustainability disclosure dengan penerbitan saham dan penerbitan obligasi dimoderasi oleh pengawasan dan pengaruh keluarga.

Hasil penelitian ini diharapkan dapat memperkaya pandangan calon investor tentang penerbitan saham dan obligasi dalam mempengaruhi sustainability disclosure dengan dimoderasi pengawasan dan pengaruh keluarga.

\section{TINJAUAN TEORITIS \\ Teori Agensi}

Hubungan kontrak antara pemegang saham dan manajemen dalam menjalankan tugas-tugas manajemen atas nama pemegang saham, dimana agen berwenang dalam pengambilan keputusan itu yang dimaksud dengan teori agensi (Jensen dan Meckling, 1976). Persoalan pemisahan risiko antara pemegang saham dan manajemen serta persoalan ketidak selarasan antara pemegang saham dengan manajemen eksekutif yang menjadikan pepusat Teori agensi (Fama dan Jensen, 1983).

Adanya asimetri informasi merupakan ancaman etiket yang terjadi dalam teori keagenan. Asimetri informasi terjadi bilamana salah satu pihak dalam hal ini manajemen yang bekerja atas nama pemegang saham lebih banyak tahu akan informasi tentang kegiatan dan aspirasinya ketimbang pemegang saham karena kurangnya hak pengawasan terhadap agen. Pengarahan Asimetri informasi pada pemisahan tugas antara kepemilikan dan manajemen berpotensi mengundang konflik antara pemegang saham dengan manajemen.

Instrumen untuk menekan asimetri informasi antara orang dengan investor, pemegang saham dan kreditur dalam suatu perusahaan dapat menggunakan sustainability disclosure, menurut teori agen (Gavanna, 2017). Konsep kerja yang bermanfaat untuk mengkaji hubungan antara format tata kelola perusahaan, penentuan format kapital, pengungkapan sukarela dan kepemilikan diberikan dalam teori agensi. Mekanisme-mekanisme pengawasan dapat digunakan untuk menekan persoalan agensi. Ada beberapa mekanisme pengawasan yang dapat digunakan untuk mengurangi persoalan agensi, seperti otonom direktur, leverage, keserasian otoritas antara sharehokder dengan pengelola, dan proteksi minoritas shareholder (Fama, 1980).

Persoalaan agensi berlainan antara perusahaan milik keluarga dan perusahaan bukan milik keluarga, sebab mereka bukan golongan yang sama (Chua et al., 2012). Miller et al, 2011 memanfaatkan teori keagenan sebagai landasan untuk mengkaji bisnis keluarga. Dua jenis perselisihan keagenan yang ditunjukkan teori keagenan yaitu perselisihan keagenan tipe pertama antara pengelola dengan pemilik keluarga, dan antara keluarga dengan shareholder diluar keluarga (tipe kedua).

Teori Institusional

Suatu organisasi ingin memperoleh keserasian kelangsungan hidup dengan memadukan etika dan peraturan kelembagaan berlandaskan pada teori Institusional. Dimana teori institusional merupakan suatu organisasi yang terbentuk karena adanya tekanan dari 
lingkungan (DiMaggio \& Powell, 1983). Kerangka untuk menganalisis alternatif strategi perusahaan dengan ukuran sosial telah diberikan dalam teori institusional. pandangan legitimasi dan pandangan stakeholder yang terkandung didalam teori tersebut. Brown and Deegan, (1998) menyatakan bahwa suatu organisasi atau perusahaan berusaha membuktikan akan kinerjanya yang dijalankan sesuai dengan pandangan legitimasi yang membatasi pengembangan dan etika masyarakat.

Dalam Fernandez-Feijoo et al., (2014) tentang pandangan shareholder, bahwa untuk memenuhi harapan, menciptakan pemahaman kalangan pemangku kepentingan tertentu sustainability disclosure sebagai fasilitasnya. Bukan saja terpusat pada nilai-nilai masyarakat saja akan tetapi terpusat juga pada kepercayaan institusional yang sudah ada itulah teori institusional. Pendirian ini dianggap sebagai cermin dari sistem nilai sosial (Chen \& Roberts, 2010). Sebuah organisasi atau perusahaan akan membuahkan pengungkapan berkelanjutan supaya serasi dengan etika dan keyakinan yang diperoleh secara sosial, merupakan perspektif teori institusional,

Perusahaan bagaikan format kelembagaan dari berbagai personel dan golongan dengan keperluan bersama, nilai, kebijakan, dan praktik yang dapat diinstitusikan merupakan pandangan teori institusional. Dalam Zabihollah et al (2017) pemusatan teori institusional merupakan aspek struktur sosial, kepraktisan, rasionalisasi, legitimasi, dan proses menetapkan pedoman serta praktik terbaik sesuai dengan standar, etika, kebijakan dan hukum yang berlaku.

\section{Sustainability Disclosure}

Laporan yang dipublikasikan perusahaan yang berisi tentang dampak ekonomi, lingkungan dan sosial sebagai akibat operasional definisi sustainability disclosure (GRI, 2013). Dengan sustainability disclosure ini perusahaan dapat menolong dalam menilai, menginterprestasikan dan menginformasikan kinerja ekonomi, tata kelola, lingkungan, dan sosial, serta kemudian menentukan sasaran, dan mengorganisasikan peralihan secara lebih efektif. Kegunaan Sustainability disclosure untuk (PWC, 2016):

1. Pengedalian risiko sustainability perusahaan dengan lebih baik.

2. Mengorganisasian Stakeholder secara kian tertata.

3. Menentukan sasaran dan meningkatkan kinerja.

4. Pedoman terhadap perusahaan lain di industri yang sama.

5. Meningkatkan keterandalan, akuntabilitas dan transparansi.

6. Meningkatkan merek dan nama baik perusahaan sebagai organisasi yang bertanggung jawab.

Persoalan sosial beserta lingkungan menjadikan masyarakat akan lebih sadar dan tertarik. Dalam dua dekase terakhir ini menunjukkan bahwa media masa telah berhasil meningkatkan pengungkapan sosial perusahaan yang lebih banyak. Maka dari itu banyak perusahaan berupaya menyampaikan informasi tentang pengungkapan sukarela, yakni "Corporate Social Responsibility" menjadi sustainability disclosure untuk memenuhi permintaan informasi yang diharapkan" (Reverte, 2009):

- pemodal dan stakeholder lain terdorong menilai kinerja sosial dan lingkungannya; dan

- peluang kinerja dan pemahaman risiko finansial masa depan suatu perusahaan tergantung pada kualitas data non-finansial.

Penyusunan kerangka umum sustainability disclosure berlandaskan pada pelaporan keberlanjutan GRI, yang memiliki fungsi untuk membuat laporan keberlanjutan organisasi, sesuai ukuran, sektor, atau lokasinya (Global Reporting Initiative, 2013). Penetapan prinsip dan indikator dalam kerangka kerja sustainability disclosure dimanfaatkan untuk mengungkapkan dan menilai kinerja ekonomi, sosial dan lingkungan perusahaan yang memusatkan pada konsep "meterialilitas" (PWC, 2016). 
G4 (Generasi Keempat) merupakan versi terbaru GRI untuk saat ini, yang berisi tentang panduan sustainability reports, disiarkan secara resmi pada Mei tahun 2013 menyampaikan arahan global untuk mengungkapkan kinerja berkesinambungan. Perusahaan merasa terbantu adanya pemahaman panduan GRI, sehingga dapat membentuk komunikasi dalam mengekspresikan upaya sustainability perusahaan secara efisien berdasarkan kriteria internasional serta memungkinkan penyesuaian antar perusahaan.

Prinsip-prinsip pelaporan, acuan penerapan dan pengungkapan standar terdapat dalam pedoman pelaporan keberlanjutan (GRI, 2013). Isi laporan, memastikan mutu laporan, dan menentukan batasan laporan ditetapkan oleh prinsip-prinsip pelaporan dan bimbingan bantuan. Pengungkapan kriteria antara lain indikator kinerja dan pendekatan manajemen, strategi dan profil. Dalam Indikator kinerja keseluruhan terdapat 91 indikatot, yaitu sembilan kinerja tanggung jawab produk $(\mathrm{PR})$, sembilan ekonomi (EC), sebelas sosial (SO), dua belas hak asasi manusia (SDM), enam belas praktek tenaga kerja dan kelayakan kerja (LA), dan tiga puluh empat lingkungan (EN).

Sustainability disclosure diperlukan dalam suatu perusahaan terkait dengan hasil pembangunan berkelanjutan untuk pengukuran kinerja pada berbagai indikator. Pada waktu penyusunan laporan telah tersedia untuk publik, pemodal dan pemangku kepentingan lainnya, selanjutnya laporan tersebut dipergunakan untuk mengukur dirinya sendiri, dan pelaksanaan tingkat usaha serta untuk mempromosikan keberlanjutan.

\section{Socioemotional Wealth}

Perbedaan antara perusahaan keluarga dan perusahaan non keluarga secara kesemuanya tidak dapat dijelaskan oleh satu teori saja yaitu Teori keagenan (Gavanna, 2017). Lebih lanjut diungkapkan bahwa pengembalian finansial bukanlah ketertarikan semata anggota keluarga akan tetapi mereka sangat khawatir pula akan faedah nonekonomi yang sudah didapatkannya melalui usaha (Gomez-Mejia et al., 2007). Sehingga disini terlihat adanya perbedaan pada perusahaan keluarga dan non keluarga.

Pendekatan

Socioemotional

Wealth (SEW) dapat digunakan untuk memberikan penjelasan tentang perbedaan kedua jenis perusahaan tersebut. Lebih lanjut Pendekatan Socioemotional Wealth menjelaskan bahwa pendekatan ini yang menjelaskan bahwa faedah kepemilikan keluarga bermula dari bidang bisnis non ekonomi (Gomez-Mejia et al., 2007), dan berlandaskan pada perilaku teori agensi (Wiseman dan Gomez-Mejia, 1998). Menurut pendekatan socioemotional wealth, dengan pengendalian usaha anggota keluarga akan mendapatkan saham. Sedangkan menurut penelitian Gottardo dan Moisello., (2014) yang mendasarkan pada pendekatan socioemotional wealth memperlihatkan bahwa struktur modal, keterlibatan pemangku kepentingan, pelestarian nilai penciptaan tata kelola perusahaan, pengambilan risiko, pengelolaan lingkungan diperlukan suatu kemauan perusahaan keluarga.

Penelitian Kellermanns et al (2012) memperlihatkan bahwa dalam pencarian SEW terdapat dua dampak, yaitu dampak positif maupun dampak negatif. Prososial dan dukungan yang positif dapat dijadikan dampak positif pencarian SEW, sedangka biaya usaha keluarga dan komponen utama pada perusahaan dapat dijadikan sebagai dampak negatifnya. Eddleston dan Kidwell (2012) membuktikan bahwa dalam kondisi tertentu pelestarian SEW bisa memposisikan usaha pada risiko dan mendatangkan kerugian bagi para pemangku kepentingan, seperti pemegang saham minoritas.

$$
\text { Lima aspek keafektifan }
$$

"endowment" dalam pandangan SEW yang belum pernah dikaji, kemudian oleh Berrone et al. (2012) menjelaskan lima aspek keafektifan "endowment' yaitu "pengawasan dan pengaruh keluarga", 
"ikatan sosial keluarga", "ikatan emosional : antara keluarga dan dunia usaha dalam anggota keluarga yang terlibat di dalamnya", "identifikasi anggota keluarga dengan tegas" dan "pembaharuan obligasi keluarga untuk perusahaan" dengan susunan keluarga.

Pengawasan dan pengaruh anggota keluarga dijadikan acuan pada aspek kesatu. Anggota keluarga yang memberikan pengawasan terhadap keputusan strategi merupakan salah satu karakteristik yang membedakan perusahaan keluarga (Schulze, Lubatkin, \& Dino, 2003). Pengawasan atas keputusan strategis memiliki dampak langsung terhadap usaha lewat CEO yang bermula dari anggota keluarga, secara tidak langsung akan menunjuk anggota-anggota tim manajemen puncak.

Pelestarian

pengawasan

kepemilikan Usaha keluarga untuk mengamankan efektivitas dan sebagai sumber SEW sendiri merupakan bukti kesanggupan yang lebih besar dari bisnis keluarga (Gomez-Mejia et al., 2007). Fokus untuk mempertahankan pengawasan kepemilikan yang berpengaruh terhadap struktur modal perusahaan keluarga merupakan pemikiran dan kepedulian SEW. Perusahaan keluarga condong memanfaatkan modal dari hutang rekanrekan mereka ketimbang menggunakan modal dari keluarga sendiri (Gottardo dan Moisello 2014).

\section{Penerbitan Saham}

Saham merupakan bukti kepemilikan suatu perusahaan yang menerbitkan bukti kepemilikan tersebut dan pengakuan atas sebagian harta serta pemasukan perusahaan (Jones et al, 2012). Menurut IDX, saham merupakan bukti penglibatan modal atau kepemilikan atas perusahaan. Dari definisi tersebut dapat disimpulkan bahwa saham merupakan bukti kepemilikan atas penanaman modal dalam perusahaan dan pemodal berwenang atas sebagian harta dan pemasukan perusahaan.
Jika suatu perusahaan ingin meningkatkan atau menambah modalnya, maka salah satu cara yaitu dengan menerbitkan saham. Perusahaan yang menerbitkan saham diharuskan menginformasikan tentang keadaan usahanya dibidang fianansial, operasional produksi, hal yang berhubungan dengan aktivitas usahanya kepada masyarakat muapun tata kelolanya, pernyataan Undang-Undang Nomor 8 Tahun 1995 tentang pasar modal. Seiring berjalannya waktu, Perilaku perusahaan terhadap lingkungan dan sosial telah menjadi pemikiran para pemangku kepentingan disamping laporan finansialnya. untuk itu perusahaan dalam memberikan laporan kinerjanya juga termasuk sosial dan lingkungan melalui sustainability disclosure.

Sustainability disclosure merupakan informasi non finansial perusahaan. Menurut Healy dan Palepu (2001) informasi non finansial perusahaan dapat menekan kecemasan investor tentang risiko investasi mereka. Maka perusahaan memanfaatkan sustainability disclosure sebagai sarana komunikasi agar dapat mempengaruhi pemikiran pemodal dari risiko di perusahaan (Gavanna, 2017).

\section{Penerbitan Obligasi}

Menurut Jones et al (2012) deskripsi sederhana obligasi adalah surat bukti hutang jangka panjang yang mewakili kewajiban kontraktual emiten. Investor memberikan pinjaman uang kepada entitas, dimana entitas telah setuju akan melunasi pokok pinjaman disertai bunganya saat tanggal jatuh tempo kemudian entitas menerbitkan obligasi yang dibeli oleh pemodal. Pengertian obligasi sebagai penanaman modal berbentuk hutang dimana investor meminjamkan uang kepada entitas dalam batas waktu tertentu dengan tingkat bunga variabel atau tetap. Obligasi yang sudah diterbitkan dan dibeli para pemodal dimanfaatkan perusahaan untuk mendanai berbagai proyek dan aktivitas. 
Peningkatan maupun penambahan modal, perusahaan dapat melakukan penerbitan saham atau penerbitan obligasi. Perusahaan dalam meningkatkan atau menambah modal wajib menginformasikan tentang laporan finansial dan non finansial kepada pemangku kepentingan, yang nantinya oleh pemangku kepentingan digunakan untuk pengambilan kepurusan dalam pembelian obligasi. Perusahaan beranggapan bahwa pelaporan finansial saja tidak lagi mencukupi kebutuhan para pemegang saham dan pemangku kepentingan, akan tetapi informasi berupa laporan kinerja perusahaan secara keseluruhan pada sustainability disclosure tersebut yang dapat mencukupi kebutuhan pemegang saham dan pemangku kepentingan. Perilaku yang positif pada sustainability disclosure dicerminkan oleh kondisi finansial perusahaan yang lebih baik, sesuai pendapat Francis et al (2005).

\section{Penelitian Terdahulu}

Dari sekian banyak penelitian yang telah dilakukan tentang hubungan antara sustainability disclosure dengan cost of equity capital (Carmelo Reverte, 2011) dengan penelitiannya hubungan antara mutu penyampaian pertanggungjawaban CSR dengan biaya kapital ekuitas. Hasil penelitian hubungan antara tingkat pengungkapan CSR dan cost of equity capital adalah negatif signifikan. Demikian juga dengan penelitian Reverte, menghasilkan hubungan negatif antara mutu pelaporan CSR dan cost of equity capital pada perusahaan-perusahaan yang beroperasi di manufacturing yang peka terhadap lingkungan. Kesimpulan bahwa untuk menekan asimetri informasi anatara manajer dan investor dibutuhkan pelaporan CSR bagian dari sarana komunikasi perusahaan, atau suatu pelaporan tanggung jawab sosial perusahaan yang wajib dengan tujuan mendapatkan hasil penilaian yang lebih tepat.

Pengujian hubungan anatra tanggungjawab sosial (CSR) perusahaan pada biaya kapital ekuitas dari penelitian
El Ghoul, Omrane, C.Y. Kwok, R. Mishra, (2011) menunjukkan hasil yang berlainan. Penelitian tersebut dilakukan untuk memperkirakan biaya modal ekuitas perusahaan memakai beberapa pendekatan, diperoleh hasil bahwa pembiayaan modal ekuitas lebih murah dengan ditunjukkannya suatu penilaian CSR yang lebih baik. Untuk menekan biaya modal perusahaan pada investasi diperlihatkan dalam penelitian ini dengan meningkatkan hubungan pekerja yang bertanggung jawab, kebijakan lingkungan, dan strategi produk kontribusi secara substansial. Meningkatnya biaya modal perusahaan terjadi pada partisipasi manufactur tembakau dan tenaga nuklir merupakan hasil penelitian lainnya. Penilaian lebihtinggi dan risiko lebih rendah dapat dimiliki oleh perusahaan dengan cara melaksanakan praktek-praktek yang bertanggung jawab sosial, merupakan temuan yang mendukung argumen dalam penelitian tersebut.

Disamping itu Giovanna Campopiano dan Alfredo De Massis (2014) di penelitian membahas tentang penerbitan sustainability disclosure dalam perbedaan perilaku perusahaan keluarga dan non keluarga, dengan kajian bagaimana pelaporan CSR dipengaruhi oleh pengaruh keluarga pada organisasi bisnis. Teori institusional yang dijadikan pengembangan argumen di sini, dengan memanfaatkan bukti empiris yang dihimpun melalui analisis laporan

CSR pada 98perusahaanbesar dan menengah di Italia. Hasil penelitian ini menunjukkan bahwa kebanyakan perusahaan keluarga menyajikan laporan CSR kurang memadai dengan ukuran CSR dan memposisikan pada penonjolan tema CSR yang tidak sama.

Penelitian selanjutnya oleh ( Gavana, 2017 ) yang meneliti tentang perilaku perusahaan terhadap pemakaian sustainability disclosure untuk memudahkan peningkatan kapital eksternal dan dampak pemimpin pada pengungkapan. Pemanfaatan indikator pengungkapan yang dibentuk berlandaskan sustainability reports, bagi 
sampel 230 perusahaan Italia yang tercatat. Gavana menerangkan bahwa kerentanan perusahaan dalam mengungkapkan terlihat pada saat rencana penerbitan saham atau obligasi. Pada kasus penerbitan ada efek moderat, akan tetapi pada kasus penerbitan obligasi pengawasan keluarga tidak mempengaruhi pengungkapan. Seorang CEO keluarga, memajukan rasa pengenalan keluarga dengan usaha, memajukan pengungkapan.

\section{Kerangka Pemikiran}

Peningkatan modal eksternal demi kontinuitas Perusahaan merupakan upaya yang dilakukan oleh perusahaan di Indonesia. Penerbitan saham atau obligasi dapat dilakukan untuk meningkatan atau menambah modal perusahaan. Investor dan stakeholder merupakan sasaran perusahaan untuk meningkatkan atau menambah modal dengan cara menerbitkan saham atau obligasi. Para pemodal dan pemangku kepentingan mengevaluasi dan menetapkan alternatif apakah akan membeli saham atau obligasi didasarkan pada data finansialnya dan sustainability disclosure yang nantinya akan dipakai juga dalam mengevaluasi aktivitas perusahaan.

Menurut teori institusional, perusahaan beranggapan bahwa sustainability disclosure ada, akibat desakan masyarakat, untuk mempengaruhi pemahaman masyarakat atas perusahaan yang telah mendapatkan pengesahan guna meneruskan aktivitas operasional (Branco \& Rodrigues, 2008). Selain itu sustainability disclosure merupakan alat untuk mencukupi keinginan dan mencetak pemahaman komunitas stakeholder (Fernandez-Feijoo et al, 2014). Dengan kata lain sustainability disclosure disajikan untuk mempengaruhi pemahaman masyarakat terhadap perusahaan agar dapat mencukupi keinginan dan membentuk pemahaman para pemangku kepentingan, hal ini dilakukan apabila perusahaan akan menerbitkan saham atau obligasi

Teori lain yang mendukung penelitian ini selain teori institusional, yaitu teori agensi. Perusahaan keluarga dan non keluarga dalam perencanaan penerbitan saham atau obligasi memiliki perbedaan yang utama, yaitu pada kepemilikan saham dominan dan pengawasannya. Asimetri informasi yang memiliki kekuatan timbulnya konflik ini akibat dari pemisahan antara kepemilikan dan pengawasan. Gavana (2017) mengungkapkan bahwa berdasarkan teori agensi, sustainability disclosure adalah sarana untuk menekan asimetri informasi antara manajemen dengan para pemodal. 
ISSN 1412-2936

EISSN 2549-7308

\section{Kerangka Pemikiran}

Variabel Independen
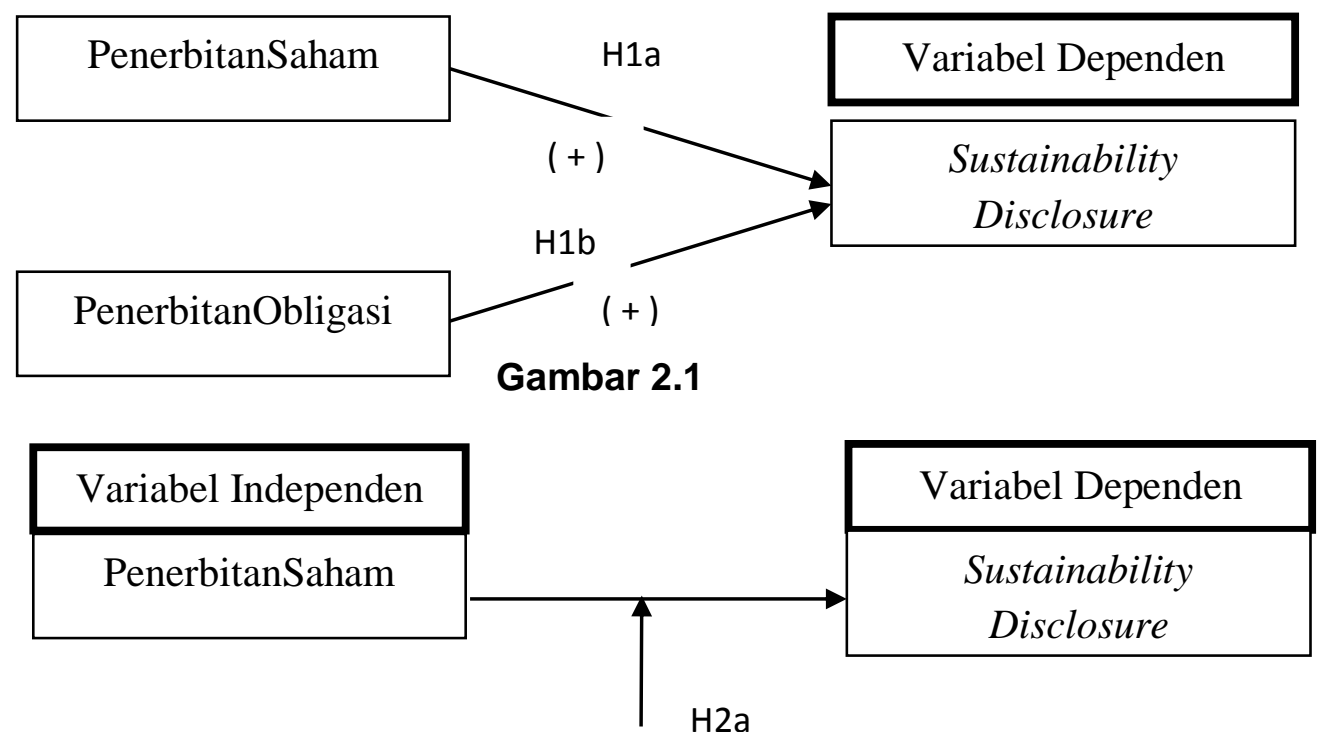

$\mathrm{H} 2 \mathrm{a}$

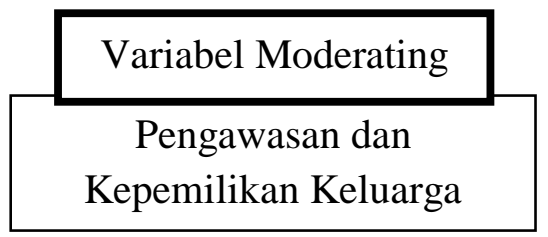

Gambar 2.2

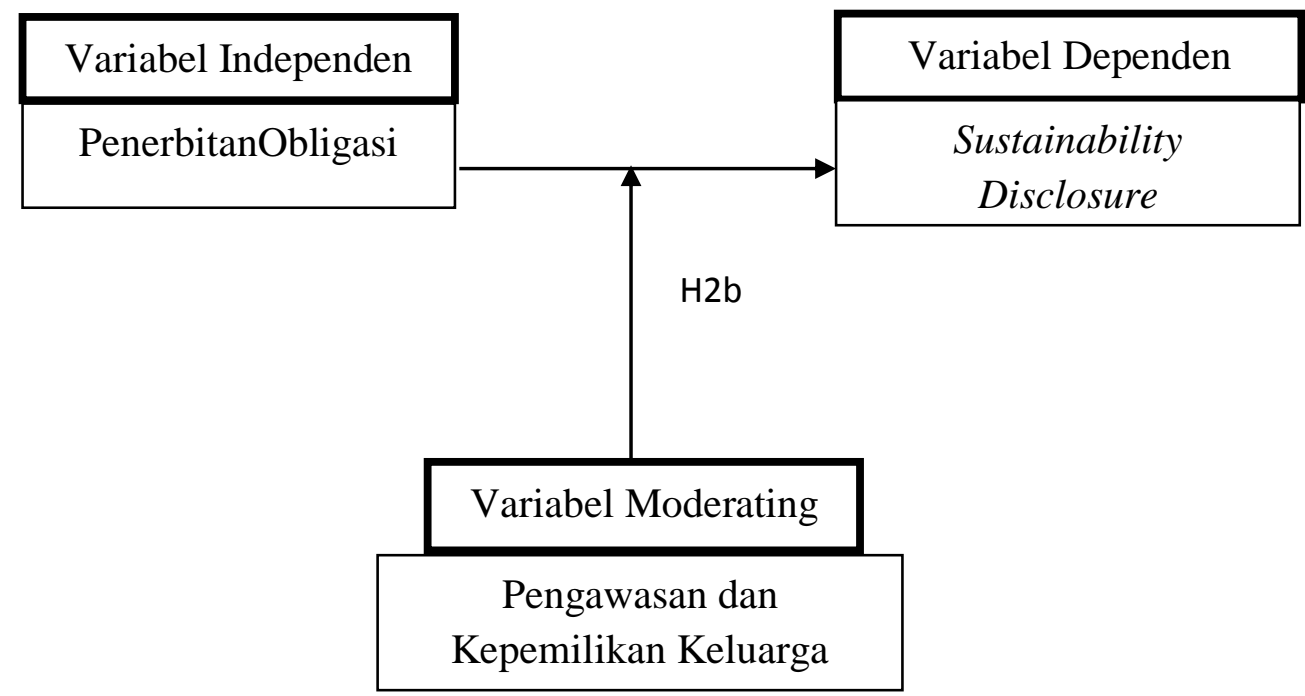

Gambar 2.3

Hipotesis

Pengaruh Penerbitan Saham terhadap Sustainability Disclosure
Penelitian sebelumnya yang dilakukan oleh Gavana (2017) sudah menguji berdasarkan teori institusional 
dan teori agensi korelasi antara penerbitan saham dengan sustainability disclosure. Dalam teori institusional, untuk mempengaruhi pemahaman masyarakat tentang perusahaan dan meningkatkan pengukuhan perusahaan agar dapat meneruskan operasional menggunakan sustainability disclosure (Branco dan Rodrigues, 2008). Selain itu sustainability disclosure sebagai alat untuk mencukupi keinginan bagi komunitas pemodal tertentu (FernandezFeijoo et al, 2014). Hingga saat dengan melakukan pengungkapan sustainability disclosure yang memiliki nilai tinggi dijadikan dasar bagi perusahaan untuk menerbitan saham dan perusahaan menciptakan pemahaman yang positif pada pemodal. Bukti kepemilikan diterbitkan perusahaan dan pengakuan atas sebagian harta serta pendapatan perusahaan merupakan definisi saham (Jones et al, 2012).

Gavanna (2017), pengungkapan sustainability disclosure diharapkan dapat menekan asimetri informasi sebagai akibat adanya konflik antara pengelola dan stakehoder sehubungan dengan sikap tanggungjawab sosial, menurut teori agensi.

Sustainability

disclosure

merupakan informasi non finansial yang dapat menekan kecemasan pemodal tentang risiko investasi yang telah dilakukan (Healy dan Palepu, 2001). Untuk itu hipotesisi yang dapat ditarik, perusahaan akan menyajikan sustainability disclosure tinggi sehubungan dengan perencanaan perusahaan untuk menerbitkan saham :

Hipotesis 1A : Secara positif Sustainability Disclosure mempengaruhi dalam penerbitan saham

\section{Pengaruh Penerbitan Obligasi terhadap Sustainability Disclosure}

Penerbitan obligasi juga memakai Teori institusional dan teori agensi. Menurut teori institusional, pemahaman masyarakat tentang perusahaan dan peningkatan atau penambahan legalitas perusahaan untuk dapat meneruskan aktivitas operasionalnya digunakan sustainability disclosure untuk mempengaruhi (Branco dan Rodrigues, 2008). Disamping itu sustainability disclosure merupakan alat demi terpenuhinya harapan komunitas pemodal tertentu (Fernandez-Feijoo et al, 2014). Sustainability disclosure berperan dalam informasi sosial dan lingkungan juga berperan dalam informasi finansial yang mendapatkan penilaian positif oleh pemodal atas informasi tersebut (Anderson dan Frankle, 1980). Untuk mendapatkan tanggapan yang positif dari para investor dalam rencana penerbitan obligasi perusahaan wajib mengungkapkan sustainability disclosure.

Potensi munculnya konflik akibat asimetri informasi dalam hal pemisahan antara pemilik dengan manajemen, menurut teori agensi. Asimetri informasi yang ditimbulkan karena adanya konflik antara pihak pemegang saham dan pihak pengelola untuk perilaku tanggungjawab sosial dapat ditekan dengan pengungkapan sustainability disclosure, menurut pandangan dari teori agensi. (Fama, 1980). Penjelasan tentang kesepakatan hutang obligasi dan kesepakatan imbalan pengelola dapat memanfaatkan Sustainability disclosure (Reverte, 2009).

Jones et al (2012) secara sederhana menjabarkan Obligasi, yaitu semacam kewajiban kontraktual emiten atau sering disebut juga dengan alat hutang jangka panjang. Sikap positif terhadap sustainability disclosure ditunjukkan oleh perusahaan yang memerlukan pembiayaan eksternal lebih besar. Berdasarkan hal tersebut, sikap positif dalam pemberian tingkat sustainability disclosure yang tinggi terlihat pada perusahaan yang berencana menerbitkan obligasi (Francis el al, 2005).

$\begin{aligned} \text { Hipotesis 1B : } & \text { Secara positif } \\ & \text { Sustainability } \\ & \text { Disclosure } \\ & \text { mempengaruhi } \\ & \text { penerbitan obligasi }\end{aligned}$


Hubungan antara Penerbitan Saham dengan Sustainability Disclosure Dimoderasi oleh Pengawasan dan Pengaruh Keluarga

Terdapat dua macam konflik keagenan dalam teori agensi, yaitu konflik tipe pertama antara pemilik dalam hal ini keluarga dengan manajemen, sedangkan konflik tipe kedua antara keluarga dengan pemegang saham bukan keluarga (Gavana, 2017). Disatu pihak, kepemilikan keluarga yang terpusat cenderung ditunjukkan oleh usaha keluarga condong dan, di pihak lain, pengetahuan yang mendalam mengenai bisnis bisa didapat oleh kepemilikan keluarga dari hubungan yang erat dengan perusahaan.

Biaya agensi dari versi pertama terkait dengan usaha non-keluarga dapat ditekan dengan memunculkan kapabilitas pengawasan yang lebih efektif (Anderson dan Reeb, 2003). Tahap kepemilikan keluarga berkorelasi negatif dengan informasi sukarela finansial dan nonfinansiaal pada laporan periode akuntansi (Akhtaruddin et al, 2009). Sehingga dapat memperlihatkan pengawasan keluarga yang lebih kukuh cendong menciptakan keserasian lebih melekat antara kepentingan pengelola dengan pemilik keluarga.

Menurut

Gavana

menunjukkan

bahwa

perusahaan

$$
\text { keluarga }
$$

penekanan asimetri informasi antara pengelola dan pemilik lebih rendah dibanding dengan perusahaan non keluarga. Sehingga menyebabkan perusahaan keluarga enggan menerbitkan sustainability disclosure serupa sistem kontrol eksternal (Chen et al., 2008). Cukup dengan pengamatan keluarga saja, jika perusahaan keluarga memerlukan pengeluaran eksternal. Maka konflik agensi jenis pertama dapat dirumuskan sebagai berikut :

$\begin{array}{lll}\text { Hipotesis 2A } & \text { : } & \text { Hubungan antara } \\ & \text { penerbitan saham } \\ & \text { dan sustainability } \\ & \text { disclosure } \\ & \text { dimoderasi oleh }\end{array}$

pengawasan dan pengaruh keluarga.

\section{Hubungan antara Penerbitan Obligasi dengan Sustainability Disclosure Dimoderasi oleh Pengawasan dan Pengaruh Keluarga}

Jenis kedua konflik agensi yaitu konflik antara keluarga dengan pemegang saham non keluarga muncul jika perusahaan keluarga lebih menentukan hutang. Perusahaan keluarga condong tidak memanfaatkan modal dari keluarga akan tetapi lebih condong memanfaatkan hutang rekanrekan mereka (Gottardo dan Moisello 2014). Dikarenakan perusahaan keluarga berat hati akan memakai modal dari anggota non-keluarga demi menjaga kontrol keluarga (Gomez-Mejia et al., 2007).

Pelestarian SEW dalam pengambilan keputusan bisnis keluarga berpengaruh terhadap efek moderat pemegang saham non-keluarga, Karena dapat menekan pengawasan keluarga dan, mengakibatkan pemanfaatan finansial tetap terjaga sehingga akan lebih tampak (Gomez-Mejiaet al., 2011), jadi pendanaan hutang yaitu alat yang memenuhi syarat untuk pelestarian SEW.

Kontrol kepemilikan keluarga secara negatif mengikat pengungkapan sukarela finansial (Akhtaruddin et al 2009). Kesimpulan dalih ini memperlihatkan bahwa perusahaan keluarga mempunyai motivasi yang kurang dalam memanfaatkan sustainability disclosure sebagai alat mempermudah meningkatkan atau menambah modal usaha non-keluarga, tapi lebih terdorong untuk meningkatkan atau menambah modal dengan hutang. Maka perumusan hipotesisnya:

Hipotesis 2B : Hubungan antara penerbitan obligasi dan sustainability disclosure dimoderasi pengawasan dan pengaruh keluarga. 


\section{METODE PENELITIAN}

Penelitian ini merupakan penelitian kuantitatif dengan menggunakan dua variabel bebas penerbitan saham dan penerbitan obligasi; satu variabel terikat sustainability disclosure ; dan dua variabel moderating pengawasan dan pengaruh keluarga. Sedangkan untuk variabel kontrol digunakan size perusahaan, profitabitas dan leverage.

Pengambil populasi perusahaanperusahaan yang tercantum dalam Bursa Efek Indonesia periode 2013-2015, secara purposive sampling. Data yang dipergunakan dalam penelitian ini data sekunder. Metode analisis data menggunakan beberapa pengujian diantaranya; Analisis statistik deskriptif dan Analisis Statistik Inferensial dengan uji asumsi klasik, yang terdiri dari; uji multikolonieritas, uji autokorelasi, uji heteroskedastisitas, uji normalitas, uji hipotesis dan ordinary least squares.

\section{ANALISIS DAN PEMBAHASAN}

Obyek penelitian ini adalah annual report dan sustainability report tahun 2013 - 2015 dengan pengambilan sampel perusahaan-perusahaan yang terdaftar di Bursa Efek Indonesia.

Tabel 4.1

Sampel Penelitian

\begin{tabular}{|c|c|}
\hline Klassifikasi & Total Perusahaan \\
\hline Sampel penelitian & 69 \\
\hline Perusahaan yang tercantum pada Bursa Efek Indonesia & 1.617 \\
\hline $\begin{array}{c}\text { Tak mempunyai informasi lengkap tentang pengukuran } \\
\text { variabel penelitian }\end{array}$ & $(37)$ \\
\hline Tak mempublikasikan laporan tahunan tahun 2013-2015 & $(23)$ \\
\hline Tak mempublikasikan sustainability report tahun 2013- \\
2015
\end{tabular}

Sumber : Data yang diolah, 2017

Berikut data deskriptif statistik variabel-variabel yang digunakan dalam penelitian ini.

Tabel 4.2

Statistik Deskriptif

Descriptive Statistics

\begin{tabular}{|l|r|r|r|r|r|}
\hline & $\mathrm{N}$ & Minimum & $\begin{array}{c}\text { Maximu } \\
\mathrm{m}\end{array}$ & Mean & $\begin{array}{c}\text { Std. } \\
\text { Deviation }\end{array}$ \\
\hline Saham & 69 & 0 & 1 &, 13 &, 339 \\
Obligasi & 69 & 0 & 1 &, 32 &, 469 \\
qFamily & 69 &, 0000 &, 2450 &, 008787 &, 0368629 \\
CEO & 69 & 0 & 1 &, 12 &, 323 \\
Size & 69 & 2,8585 & 5,1747 & 3,91125 &, 5923315 \\
Profitabilitas & 69 &,- 1536 &, 2881 &, 057435 &, 0790888 \\
Leverage & 69 &, 0004 &, 8017 &, 332567 &, 2691169 \\
Sustainability & 69 &, 2143 &, 6905 &, 392167 &, 1195697 \\
Disclosure & 69 & & & & \\
Valid N (listwise) & 69 & & & & \\
\hline
\end{tabular}

Sumber: Hasil SPSS

Dari tabel-tabel tersebut diperoleh hasil bahwa nilai average variable independen (penerbitan saham dan obligasi) memperlihatkan perusahaan pada umumnya lebih menentukan menerbitkan surat utang (obligasi) ketimbang menerbitkan efek (saham).
Variabel terikat (sustainability disclosure) nilai average perusahaan yang dijadikan sampel pada penelitian ini adalah 0,392167 .

CEO dan kepemilikan keluarga (qFamily) merupakan variabel moderating dalam penelitian ini. CEO 
dan qFamily nilainya semakin meningkat artinya bahwa perusahaan memiliki CEO nya adalah anggota keluarga dan kepemilikan saham keluarganya juga semakin meningkat juga. Rata-rata CEO 0,12 sedangkan rata-rata qFamily 0,008787 .

Variabel kontrol yaitu Size, Profitabilitas dan Leverage digunakan dalam penelitian ini. Angka 3,91125 memperlihatkan rata-rata ukuran perusahaan, dengan standar deviasi sebesar 0,5923. Laba bersih sebelum pajak dibagi total aset merupakan pengukuran profitabilitas. Pada penelitian ini diperoleh nilai rata-rata profitabilitas

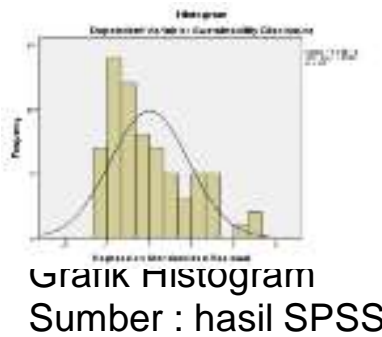

kedua Gambar diatas (gambar 4.1), memperlihatkan bahwa

penyebarannya normal dikarenakan data-data tersebar disekitar garis diagonal dan mengarah ke garis diagonal, maka asumsi normalitas dapat dipenuhi dengan model regresi. Hal ini belum cukup untuk pengambilan keputusan oleh karenanya perlu ditambahkan uji statistik non-parametik KolmogorovSmirnov (K-S). Hasilnya menunjukkan bahwa nilai signifikansi (Asymp.Sig 2tailed) sebesar 0,176 dengan demikian nilai signifikasi lebih dari $0,05(0,176>0,05)$ maka nilai residual tersebut normal.

2. Uji Multikolonieritas

nilai tolerance semua variabel melebihi nilai 0,10 , maka korelasi antar variabel tidak terjadi dengan perusahaan sebesar 0,057435 dimana standar deviasi 0,0790888. Sedangkan untuk pembagian total liabilitas dengan total aset merupakan penjelasan variabel kontrol leverage dan diperoleh nilai ratarata 0,332567 yangmana standar deviasinya 0,2691169.

\section{Pengujian Asumsi Klasik}

1. Uji Normalitas

Hasil uji normalitas yang dianalisis ditunjukkan pada pola penyebaran data dan terlihat pada gambar grafik histogram dan gambar grafik normal plot.

\section{Gambar \\ Hasil Uji Normalitas}

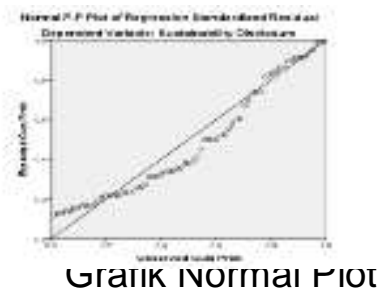

nilai yang lebih dari $95 \%$. Sedangkan VJF nilainya kurang dari 10 yang berarti terpenuhinya asumsi multikolonieritas.

3. Uji Autokorelasi

total sampel 69 , total independen 7 $(\mathrm{k}=9)$ nilai signifikan 5\% Durbin Watson (DW) akan bernilai $d u=$ 1.9126. Pada perolehan Uji Durbin Watson dihasilkan nilai sebesar 1,728 lebih kecil dari batas atas $(d u) 1,9126$ dan kurang dari 4-du $(4-1,728=$ 2,272 ) maka ada kemungkinan terjadi autokorelasi.

Uji autokorelasi dengan menggunakan run test diperoleh hasil signifikan 0,276 lebih besar dari angka signifikan 0,05 . sehingga tak terjadi autokorelasi.

4. Uji Heteroskedastisitas Hasil Uji Heteroskedastisitas

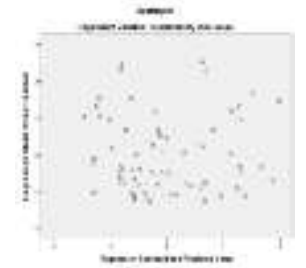

grafik scatterplot menunjukkan adanya data yang disebar secara acak dan tidak membentuk pola tertentu maka penelitian ini tidak terjadi 
heteroskedastisitas. Hasil uji heteroskedastisitas ini diperkuat dengan uji gleser.

Sumber : hasil SPSS

hasil uji glejser menunjukkan bahwa variabel independen secara signifikan tidak mempengaruhi nilai absolud residual maka dalam penelitian ini tidak terjadi indikasi heteroskedastisitas.

Hasil Uji Hipotesis

1. Koefisien Determinan $\left(R^{2}\right)$ 0,306 artinya $30,6 \%$ variasi sustainability disclosure boleh dijelaskan dengan variasi variabel independen, variabel moderating, variabel kontrol dan selebihnya sebesar $69,4 \%$ dipengaruhi faktorfaktor di luar model penelitian.

2. Uji Signifikan Simultan (Uji F)

memperlihatkan $\quad F_{\text {hitung }} \quad 2,886$ probabilitas $0,007<0,05$. Kesimpulan yaitu HA tidak berhasil ditolak dan variabel independen yaitu penerbitan sekuritas (saham dan obligasi), variabel moderating yaitu pengawasan dan kepemilikan keluarga, serta variabel-variabel kontrol yaitu size, leverage, profitabilitas berpengaruh pada variabel dependen yaitu sustainability disclosure.

3. Uji Signifikan Parameter Indiviidual (Uji T)

memperlihatkan bahwa variabel independen penerbitan obligasi secara signifikan berpengaruh terhadap sustainability disclosure probabilitas signifikansi sebesar 0,001 . Pada variabel moderating dan variabel kontrol memperlihatkan hasil nan berbeda, dimana sustainability disclosure tidak dipengaruhi secara signifikan.

Berlandaskan hasil dari model eksperimen periset, menunjukkan bahwa variabel independen secara signifikan mempengaruhi variable dependen yaitu penerbitan obligasi mengarah ke hubungan positif untuk itu hipotesis pertama ( $\mathrm{H} 1 \mathrm{~b})$ tidak berhasil ditolak, dan persamaan matematisnya

$$
\begin{aligned}
\text { Sustainability Disclosure }= & 0,437-0,022 \mathrm{SAHAM}+0,109 \mathrm{OBL}+0,783 \mathrm{qFamily}- \\
& 0,025 \mathrm{CEO}-0,021 \mathrm{SIZE}+0,147 \mathrm{PROFIT}-0,036 \mathrm{LEV}+ \\
& 0,551 \mathrm{SNM} 1+0,199 \mathrm{SNM} 2
\end{aligned}
$$

\begin{tabular}{|c|c|c|c|c|c|c|c|}
\hline \multicolumn{3}{|c|}{ Variabel } & \multirow[b]{2}{*}{ Koefisien } & \multirow{2}{*}{$\begin{array}{c}\mathrm{t}- \\
\text { statisti } \\
\mathrm{k}\end{array}$} & \multirow{2}{*}{$\begin{array}{l}\text { Prob } \\
\text { abilit } \\
\text { as }\end{array}$} & \multirow[b]{2}{*}{$\begin{array}{c}\text { Keteranga } \\
\mathrm{n}\end{array}$} & \multirow{2}{*}{$\begin{array}{c}\text { Keputus } \\
\text { an } \\
\text { Hipotesis }\end{array}$} \\
\hline Dependen & $\begin{array}{c}\text { Independe } \\
\mathrm{n}\end{array}$ & $\begin{array}{c}\text { Moderatin } \\
\mathrm{g}\end{array}$ & & & & & \\
\hline \multirow{4}{*}{$\begin{array}{l}\text { Sustainabilit } \\
\text { y Disclosure }\end{array}$} & Saham & & $-0,022$ & $-0,518$ & $\begin{array}{r}0,60 \\
8 \\
\end{array}$ & $\begin{array}{c}\text { Tidak } \\
\text { Signifikan* }\end{array}$ & $\begin{array}{c}\text { Tidak } \\
\text { Diterima }\end{array}$ \\
\hline & Obligasi & & 0,109 & 3,334 & $\begin{array}{r}0,00 \\
1 \\
\end{array}$ & Signifikan* & $\begin{array}{c}\text { Tidak } \\
\text { Ditolak }\end{array}$ \\
\hline & Saham & $\begin{array}{c}\text { Pengawas } \\
\text { an dan } \\
\text { Pengaruh } \\
\text { Keluarga }\end{array}$ & 0,551 & 0,728 & $\begin{array}{r}0,46 \\
9 \\
\end{array}$ & $\begin{array}{c}\text { Tidak } \\
\text { Signifikan* }\end{array}$ & $\begin{array}{c}\text { Tidak } \\
\text { Diterima }\end{array}$ \\
\hline & Obligasi & $\begin{array}{c}\text { Pengawas } \\
\text { an dan } \\
\text { Pengaruh } \\
\text { Keluarga }\end{array}$ & 0,199 & 1,751 & $\begin{array}{r}0,08 \\
5 \\
\end{array}$ & $\begin{array}{c}\text { Tidak } \\
\text { Signifikan* }\end{array}$ & $\begin{array}{c}\text { Tidak } \\
\text { Diterima }\end{array}$ \\
\hline
\end{tabular}

Keputusan Hipotesis 
Signifikan* : Signifikan pada tingkat kepercayaan 5\%

\begin{tabular}{lcc}
\multicolumn{3}{c}{ Hipotesis pertama (a) yaitu variabel } \\
sustainability disclosure & tidak \\
dipengaruhi secara signifikan & oleh
\end{tabular} variabel penerbitan saham, tapi mengarah ke hubungan positif tingkat kepercayaan sebesar 95\% ( $\alpha=5 \%)$ dengan demikian hipotesis pertama (a) tidak diterima. Hipotesis pertama (b) yaitu variabel sustainability disclosure dipengaruhi secara signifikan oleh variabel penerbitan obligasi dan mengarah ke hubungan positif maka hipotesis pertama (b) tidak ditolak.

Hipotesis kedua (a) yaitu hubungan antara penerbitan saham dan sustainability disclosure tidak dipengaruhi variabel moderating pengawasan dan pengaruh keluarga secara signifikan dengan demikian hipotesis tidak diterima. Pada hipotesis kedua (b) yaitu hubungan antara penerbitan obligasi dengan sustainability disclosure hubungan antara penerbitan obligasi dengan sustainability disclosure tidak dipengaruhi secara signifikan oleh variabel moderating pengawasan dan pengaruh keluarga, hal ini menunjukkan bahwa hipotesis kedua (b) tidak diterima. Inteprestasi Hasil

1. Pengaruh Penerbitan Saham terhadap Sustainability Disclosure sustainability disclosure secara positif signifikan tidak terpengaruh dengan penerbitan saham, sehingga dapat dikatakan bahwa hasil tersebut selaras dengan penelitian Gavana, (2017), menyatakan bahwa keputusan pembiayaan tidak tegantung dengan penerbitan saham dan tidak mempunyai imbas signifikan terhadap tingkat sustainability disclosure. Hasil tersebut tidak sinkron dengan teori institusional dimana sustainability disclosure merespon terhadap desakan masyarakat, untuk mempengaruhi pemahaman umum perusahaan dan mendapatkan legalitas untuk meneruskan operasi (Branco dan Rodrigues, 2008). Pengungkapan sosial dan lingkungan maksudkan sebagai alat untuk mencukupi keinginan, atau membangun pemahaman, golongan pemangku kepentingan tertentu (Fernandez-Feijoo et al, 2014).

2. Pengaruh Penerbitan Obligasi terhadap Sustainability Disclosure sustainability disclosure secara positif signifikan terpengaruh dengan adanya penerbitan obligasi. Maka hasil ini selaras dengan hasil penelitian Gavana, (2017) dan teori institusional, yang memaparkan bahwa dampak signifikan terhadap tmgkat sustainability disclosure berpengaruh dalam menentukan pembiayaan terkait dengan obligasi.

3. Pengawasan dan Pengaruh Keluarga Memoderasi Hubungan antara Penerbitan Saham dengan Sustainability Disclosure.

Hubungan antara penerbitan saham dengan sustainability disclosure tidak dimoderasi pengawasan dan pengaruh keluarga, maksudnya hubungan antara penerbitan saham dengan sustainability disclosure tidak disangkutpautkan dengan pengawasan dan pengaruh yang berasal dari anggota keluarga. Meskipun kepemilikan saham perusahaan mempengaruhi penerbitan saham tetapi indikator lain tentang penilaian pengawasan dan kepemilikan keluarga tanpa sangkutpautnya dalam tautan antara penerbitan saham dengan sustainability disclosure.

4. Pengawasan dan Pengaruh Keluarga Memoderasi Hubungan antara Penetbitan Obligasi dengan Sustainability Disclosure

secara signifikan kepemilikan keluarga tidak ada hubungannya antara penerbitan obligasi dengan sustainability disclosure.

bahwa hubungan negatif antara taraf kepemilikan keluarga dengan informasi sukarela finansial dan nonfinansial pada laporan tahunan, dan memperlihatkan bahwa kekuatan kontrol keluarga condong menghasilkan keserasian antara kepentingan pengelola dan pemilik 
keluarga akan lebih dekat, (Akhtaruddin at al, 2009).

\section{SIMPULAN, KETERBATASAN DAN SARAN \\ Simpulan}

Hasil analisis hipotesisi terhadap 69 sampel perusahaan, ada beberapa kesimpulan

1. Penyajian pengungkapan sustainability disclosure condong diberikan oleh perusahaan jikalau perusahaan merencanakan akan menerbitkan obligasi. Pernyataan tersebut memperlihatkan bahwa sustainability disclosure dipengaruhi positif signifikan oleh penerbitan saham dan penerbitan obligasi.

2. Hubungan antara penerbitan saham terhadap sustainability disclosure tidak bisa dimoderasi pengawasan dan pengaruh keluarga. Pernyataan ini memperlihatkan bahwa hubungan antara penerbitan saham terhadap sustainability disclosure tidak dipengaruhi oleh CEO keluarga. Disisi lain hubungan antara penerbitan saham terhadap sustainability disclosure dipengaruhi oleh kepemilikan keluarga.

3. CEO keluarga dapat memoderasi pengaruh penerbitan obligasi terhadap sustainability disclosure. Disisi lain pengaruh penerbitan obligasi terhadap sustainability disclosure tidak dimoderasi kepemilikan keluarga. Hal ini berarti bahwa kepemilikan keluarga tidak memperkuat atau memperlemah pengaruh hubungan antara penerbitan obligasi dan sustainability disclosure.

Keterbatasan

1. Perusahaan keluarga di Indonesia belum begitu banyak yang mengeluarkan sustainability disclosure dan menyampaikan besaran kepemilikan saham keluarga di perusahaan keluarga, maka peneliti dalam pengambilan sampel sebagian besar masih mengambil perusahaan non keluarga.
2. nilai adjusted $R^{2} 38,8$ hasil tersebut mempunyai nilai kecil hingga kedapatan komponen lain tidak di dalam bentuk penelitian ini masih banyak, yang dapat mendiskripsikan oleh sustainability disclosure lebih baik.

3. Perencanaan penerbitan saham dan obligasi dalam penelitian hanya diukur dengan metode dummy.

4. Kepemilikan keluarga merupakan pengukuran yang paling mungkin untuk menilai socioemotional wealth (SEW). Penilaian ini hanya pada dimensi yang berhubungan dengan pengawasan dan pengaruh keluarga namun tidak memperhitungkan aspek SEW lainnya.

5. Penelitian ini berfokus pada hubungan antara pengungkapan dengan pilihan pembiayaan, akan tetapi tidak menguraikan hubungan antara pengungkapan dengan keberhasilan penerbitan saham atau obligasi

\section{Saran}

Dari hasil penelitian ini dapat disampaikan beberapa saran telah disimpulkan :

1. Hasil penelitian ini masih menyampaikan bukti berdasarkan pengujian yang telah dilakukan secara umum pada perusahaan tercatat di BEl dan mempublikasikan sustainability disclosure. Penelitian berharap untuk memperluas pengkajian dengan memilah sampel selang perusahaan milik keluarga dengan bukan milik keluarga untuk mendapatkan penjabaran yang kian baik.

2. Perusahaan butuh mencermatikan komponen maupun segi lain yang mempengaruhi sustainability disclosure walaupun eksplorasi ini menunjukkan tentang perencanaan penerbitan saham dan obligasi secara signifikan sustainability disclosure. mempengaruhi

\section{DAFTAR PUSTAKA}


Ali, A., Chen, T. and Radhakrishnan, S. (2007). Corporate disclosures by family firms. Journal of Accounting and Economics, Vol. 44 No. 2, pp. 238-286.

Anderson, R.C. and Reeb, D.M. (2003). Founding-family ownership and firm performance: evidence from the S\&P 500. Journal of Finance, Vol. 58 No. 3, pp. 1301-1328.

Campopiano, G. and De Massis, A. (2014). Corporate social responsibility reporting: a content analysis in family and non-family firms. Journal of Business Ethics, Vol. 129 No. 3 , pp. 511-534.

Chua, J.H., Chrisman, J.J., Steier, L.P. and Rau, S.B. (2012). Sources of heterogeneity in family firms: an introduction. Entrepreneurship Theory and Practice, Vol. 36 No. 6, pp. 1103-1113.

El Ghoul, S., Guedhami, O., Kwok, C.C. and Mishra, D.R. (2011). Does corporate social responsibility affect the cost of capital? Journal of Banking \& Finance, Vol. 35 No. 9, pp. 2388-2406.

Gamerschlag, R., Mo"ller, K., \& Verbeeten, F. (2011). Determinants of voluntary CSR disclosure empirical evidence from Germany. Review of Managerial Science, Vol. 5, pp. 233-262.

Gao, F., Dong, Y., Ni, C. and Fu, R. (2016). Determinants and economic consequences of nonfinancial disclosure quality. European Accounting Review, Vol. 25 No. 2, pp. 287-317.

Gavana, G. (2017). The effect of equity and bond issues on sustainability disclosure. Family vs non-family
Italian firms. Social Responsibility Journal, Vol. 13, pp. 126-142.

Gomez-Mejia, L.R., Haynes, K.T., Nunez-Nickel, M., Jacobson, K.J.L. and Moyano-Fuentes, J. (2007). Socioemotional wealth and business risks in familycontrolled firms, evidence from Spanish olive oil mills. Administrative Science Quarterly, Vol. 52 No. 1, pp. 106-137.

GRI. (2013). G4 SUSTAINABILITY REPORTING GUIDELINES.

Retrieved April 2017, from http://www.globalreporting.org/res ourcelibrary/Bahasa-IndonesiaG4-Part-Two.pdf

H, W. (2008). Does the market value corporate environmental responsibility? An empirical examination. Corporate Social Responsibility and Environmental Management, Vol.15 No. 2, pp. 89-99.

Hooghiemstra, R. (2000). Corporate communication and impression management-New perspectives why companies engage in corporate social reporting. Journal of Business Ethics, Vol. 27, pp. 55-68.

Hussainey K, Salama A. (2011). The importance of corporate environmental reputation to investors. J Appl Account Res, Vol.11 No.3, pp. 229-241.

lyer, V. and Lulseged, A. (2013). Does family status impact US firms' sustainability reporting? Sustainability Accounting, Management and Policy Journal, Vol. 4 No. 2, pp. 163-189. 
Jensen, M.C. and Meckling, W.H. (1976). Theory of the firm: managerial behavior, agency costs and ownership structure. Journal of Financial Economics, Vol. 3 No. 4, pp. 305-360.

Murray, A., Sinclair, D., Power, D. and Gray, R. (2006). Do financial markets care about social and environmental disclosure? Further evidence and exploration from the UK. Accounting, Auditing \& Accountability Journal, Vol. 19 No. 2, pp. 228-255.

Nakao Y, Amano A, Matsumura K, Genba K, Nakano M. (2007). Relationship between environmental performance andfinancial performance: An empirical analysis of Japanese corporations. Business Strategy and the Environment, Vol.16 No.2, pp. 106-118.

Reverte, C. (2011). The impact of better corporate social responsibility disclosure on the cost of equity capital. Corporate Social Responsibility and Environmental
Management, Vol. 19 No. 5,, pp. 253-272.

Reverte, C. (2014). Corporate social responsibility disclosure and market valuation: evidence from Spanish listed firms. Review of Managerial Science, Vol. 10 No. 2, pp. 411-435.

Robinson M, Kleffner A, Bertels S. (2011). Signaling sustainability leadership: empirical evidence of the value of DJSI membership. $J$ Bus Ethics, pp. 493-505.

Schadewitz, H. and Niskala, M. (2010). Communication via responsibility reporting and its effect on firm value in Finland. Corporate Social Responsibility and Environmental Management, Vol. 17 No. 2, pp. 96-106.

Weber O, Scholz RW, Michalik G. (2010). Incorporating sustainability criteria into credit risk management. Business Strategy and the Environment, Vol.19 No. 1, pp. 39-50. 